\title{
KAJIAN PATOFISIOLOGIS GEJALA KLINIS DAN PSIKOSOSIAL SEBAGAI DAMPAK GANGGUAN FUNGSI TIROID PADA WANITA USIA PRODUKTIF
}

\author{
Mutalazimah, ${ }^{1,2}$, Budi Mulyono ${ }^{3}$, Bhisma Murti ${ }^{4}$ dan Saifuddin Azwar $^{5}$ \\ ${ }^{1}$ Program Studi Gizi Fakultas Ilmu Kesehatan Universitas Muhammadiyah Surakarta \\ Jl. A Yani Tromol Pos I, Pabelan, Surakarta \\ ${ }^{2}$ Mahasiswa Program Doktor Fakultas Kedokteran Universitas Gadjah Mada Yogyakarta \\ ${ }^{3}$ Bagian Patologi Klinis RSUP DR. Sardjito Yogyakarta \\ ${ }^{4}$ Bagian IImu Kesehatan Masyarakat Fakultas Kedokteran UNS \\ ${ }^{5}$ Fakultas Psikologi Universitas Gadjah Mada Yogyakarta
}

\begin{abstract}
Indonesia has not been free from iodine deficiency, demonstrated by the increased prevalence of total goitre rate (TGR) from 9.8\% in 1998, to $11.1 \%$ in 2003. New problem that occurs in endemic areas of iodine deficiency is the presence of iodine excessive, one of them as the impact of universal salt iodization program (USI) and iodiol supplementation in a long period of time. Both deficiency and excessive of iodine can result in thyroid dysfunction. Impaired thyroid function is manifest broadly on biopsychosocial aspects, which is detrimental especially for childbearing women, as a determinant of survival and quality of life for future generations. Based on the measurement of TSH and FT4, were childbearing women who suffer subclinical hypothyroidism were $2 \%$, subclinical hyperthyroidism were $26 \%$ and euthyroid were $76 \%$. Biopsychosocial characteristics that can be described from hypothyroid subjects are visible goiter, puffy face, dry skin, fatigue, decreased concentration, menorrhagia, easily upset, depressed, apathetic and withdrawn. Meanwhile, the varying percentage of subjects with subclinical hyperthyroidism showed signs and symptoms include a palpable goiter, heat intolerance, exophthalmos, tiredness, pritibial edema, muscle weakness, delicated skin, poor memory, decreased concentration, menstrual disorders, decreased sexual libido, anxiety, sleep disturbances, irritability, decreased motivation and decreased social activity. Therefore that the impact of thyroid dysfunction on a biopsychosocial characteristics, does not continue to secondary diseases, efforts are needed to increase community awareness to recognize the signs and symptoms of biopsychosocial changes. Therefore, the condition of iodine deficiency and excessive can be detected early and overcame with adequate therapy.
\end{abstract}

Keywords: Iodine Deficiency, Iodine Excessive, Thyroid Dysfunction, Biopsychosocial

\section{PENDAHULUAN}

Gangguan akibat kekurangan yodium (GAKY) merupakan salah satu masalah kesehatan masyarakat yang serius, karena berdampak sangat besar terhadap kelangsungan hidup dan kualitas sumber daya manusia. Penyebab GAKY adalah tidak tercukupinya asupan yodium di dalam tubuh, yang dikenal sebagai iodine deficiency disorder 
(IDD) (Medani et al., 2011, Delshad et al., 2010). Indonesia menjadikan GAKY sebagai salah satu masalah gizi utama, karena sejumlah 42 juta penduduk tinggal di daerah endemis GAKY, 10 juta menderita gondok dan 750 ribu menderita kretin. Hasil survei di seluruh Indonesia menunjukkan adanya peningkatan prevalensi total goitre rate (TGR) dari 9,8\% pada tahun 1998, meningkat menjadi sebesar $11,1 \%$ pada tahun 2003 (Tim GAKY Pusat, 2005).

Defisiensi yodium berkaitan erat dengan faktor geografis, seperti daerah pegunungan yang lapisan humus tanah sebagai tempat menetapnya yodium sudah tidak ada, akibat erosi tanah secara terus menerus, terkikis oleh banjir, lahar, hujan tropik pada lahan miring, tanah berkapur dan yodium larut dalam air yang terbawa sampai ke muara sungai dan laut, serta karena adanya pembakaran hutan. Beberapa kondisi geografis tersebut menyebabkan keadaan tanah, air dan bahan pangan kurang mengandung yodium. Suatu wilayah yang mempunyai karakteristik yang menyebabkan berkurangnya kandungan yodium dalam tanah ini disebut sebagai daerah endemis GAKY (Bayram et al, 2009).

Daerah endemis GAKY berisiko menyebabkan defisiensi yodium pada semua kelompok umur, mulai dari janin, neonatal, anak-anak, remaja, dewasa dan lanjut usia. Dampak dari defisiensi yodium mencakup spektrum yang sangat luas, seperti: keguguran, lahir mati, cacat bawaan, kematian perinatal, kematian bayi, kretin, gondok, hipotiroid, penurunan IQ, gangguan fungsi mental, gangguan fungsi otot, pertumbuhan terhambat dan iodine induced hyperthyroidism atau IIH (Sebotsa et al, 2009).

Permasalahan baru yang terjadi di daerah endemis IDD adalah adanya ekses yodium, sebagai dampak dari program eliminasi terhadap defisiensi yodium berupa universal salt iodization (USI) dan suplementasi yodiol dalam jangka waktu yang relatif panjang (Fountoulakis et al., 2007, Henjum et al, 2010). Tidak berbeda dengan defisiensi yodium, ekses yodium juga berisiko terhadap kesehatan, seperti mengakibatkan tiroiditis, hipertiroidisme, hipotiroidisme, goiter dan berbagai dampak IIH dengan berbagai manifestasi, seperti meningkatnya denyut nadi, menurunnya berat badan, keringat berlebihan dan tremor. IIH juga berisiko terhadap autoimmune thyroid disease (AITD) (Fountoulakis et al., 2007, Henjum et al, 2010).

Beberapa penelitian telah menemukan adanya kasus ekses yodium di daerah endemis, seperti Alsayed, et al (2008) menemukan 54,8\% wanita di Mesir mengalami ekses yodium dan berkorelasi dengan kondisi hipotiroidisme subklinis. Penelitian Mutalazimah dan Asyanti (2010), menemukan ekses yodium sebesar $10 \%$ pada anak sekolah dasar di Kecamatan Cangkringan Kabupaten Sleman. Penelitian Henjum, et al 
(2010) menunjukkan hasil yang sangat ekstrim, yakni menemukan $84 \%$ anak sekolah di daerah endemis Saharawi Algeria mengalami ekses yodium. Penelitian Hermann, et al (2004) dan Lamfon (2008) juga menemukan kecenderungan hipertiroid subklinis, yakni adanya penurunan serum thyroid stimulating hormone (TSH) pada subjek di daerah endemis defisiensi yodium, sedangkan kadar free T4 (FT4) atau hormon tiroksin masih dalam ambang normal (Hermann et al., 2004, Lamfon., 2008).

Berbagai masalah yang berkaitan dengan yodium dan fungsi tiroid pada kelompok wanita, terjadi 4 - 10 kali lebih sering dibandingkan dengan pada pria, khususnya pada wanita masa usia produktif (Fountoulakis et al., 2007, Lamfon., 2008, Watt, 2009). Tidak terdeteksinya wanita usia produktif yang menderita defisiensi yodium, akan menimbulkan risiko kehamilan yang berkaitan dengan kematian janin, dengan prevalensi sampai $79 \%$. Selain itu, adanya peningkatan congenital hypothyroidism, kretinisme, keterbelakangan mental, gangguan perkembangan psikomotor dan menurunnya kecerdasan pada anak yang akan dilahirkan, karena IQ anak menjadi lebih rendah 4 sampai 7 poin (Wang et al., 2009, Charlton, 2010).

Dewasa ini kajian mengenai dampak defisiensi dan ekses yodium telah meluas, tidak saja dampak terhadap aspek biologis (klinis dan fisik), tetapi juga terhadap aspek psikososial yang sangat berkaitan dengan kondisi gangguan metabolisme yodium. Dengan demikian, tanda dan gejala yang diakibatkan oleh defisiensi dan ekses yodium, merupakan hasil interaksi dari aspek biologis, psikologis dan sosial atau yang lebih dikenal sebagai pendekatan model biopsikososial.

Model biopsikososial menyatakan bahwa kesehatan, sakit dan penyakit adalah hasil dari interaksi antara faktor biologis, psikologis dan sosial melalui mekanisme perbedaan antara proses patofisiologi yang menyebabkan penyakit dan persepsi seseorang tentang kesehatan dan akibat-akibatnya, yang disebut penyakit (Brown et al., 2005, Novack et al., 2007). Model biopsikososial juga menjelaskan efek psikologis dan sosial dari risiko penyakit, pencegahan, kepatuhan pengobatan, morbiditas, kualitas hidup dan kelangsungan hidup. Model biopsikososial pada iodine disorder, didasarkan pada berbagai tanda dan gejala defisiensi dan ekses yodium yang bermanifestasi pada aspek biologis, yakni yang ber-kaitan dengan fisik, klinis, fisiologis; aspek psikologis, yakni yang berkaitan kondisi psikis; dan aspek sosial, yakni yang berkaitan dengan interaksi individu dengan lingkungan sosialnya (Guan et $a l, 2008)$.

Pendekatan biopsikososial didasarkan pada beberapa hasil peneli- 
tian yang menemukan adanya keterkaitan antara hasil pemeriksaan klinis, psikologis dan hasil pemeriksaan biokimia pada anak-anak dan orang dewasa yang menderita defisiensi yodium dan hipotiroid. Termasuk diantaranya, ditemukannya 28\% anak sekolah dasar di Kecamatan Cangkringan Kabupaten Sleman, dengan status yodium rendah, ternyata mempunyai gangguan juga pada status biologis-psikososial. Dengan demikian terdapat hubungan yang signifikan antara status yodium dalam urin dan status biologis-psikososial pada anak sekolah dasar (Mutalazimah dan Asyanti, 2010).

Brown, et al (2005) menemukan beberapa domain dari model biopsikososial yang berkaitan dengan hipotiroidisme, yakni: aspek biologis, mencakup central nervous system (CNS), muskuloskeletal, kardiovaskular, gastrointestinal, eye-ear-nose-throat (EENT), genito urinary, general dan radiologi; aspek psikologis, meliputi mood disorder dan stress dengan berbagai gejala depresi seperti gangguan tidur, penurunan aktivitas, kurang berenergi, penurunan konsentrasi, gangguan nafsu makan dan gangguan psikologis lain, seperti mudah panik, cemas, depresi, fobia, iritabilitas dan mudah marah; dan aspek sosial, meliputi rendahnya rasa percaya diri, mudah terlibat konflik dengan orang lain, kurang bisa memahami orang lain, membatasi interaksi dengan orang lain (Watt., 2009, Brown et al., 2005) .
Penelitian ini bertujuan untuk mengidentifikasi adanya kasus gangguan fungsi tiroid, baik karena defisiensi maupun ekses yodium dengan pengukuran kadar TSH dan FT4 dan menggali karakteristik biopsikososial yang berkaitan dengan dampak dari gangguan fungsi tiroid tersebut, pada wanita usia produktif di daerah endemis defisiensi yodium. Selain itu penelitian ini juga membahas mekanisme patofisiologis dari karakteristik biopsikososial yang disebabkan oleh gangguan fungsi tiroid.

\section{METODE PENELITIAN}

Penelitian ini merupakan penelitian deskriptif, dengan populasi sasaran adalah wanita usia produktif berusia 20 - 35 tahun, yang tinggal di daerah endemis defisiensi yodium. Populasi sumber adalah wanita usia produktif berusia 20 - 35 tahun di Kecamatan Selo Kabupaten Boyolali dan Kecamatan Cangkringan Kabupaten Sleman. Sampel penelitian sebanyak 50 subjek, diambil dengan teknik simple random sampling.

Identifikasi terhadap gangguan fungsi tiroid, baik yang diakibatkan oleh defisiensi maupun ekses yodium, dilakukan dengan cara melakukan pengukuran hormon tiroid, yakni TSH dan FT4, menggunakan metode ELISA yang dilakukan di Laboratorium Patologi Klinis RSUP Dr. Sardjito Yogyakarta. Sementara itu, karakteristik biopsikososial sebagai dampak 
dari gangguan fungsi tiroid, diukur menggunakan kuesioner yang berisi item-item tanda dan gejala yang mewakili domain-domain biologis dan psikososial, yang dirujuk dari hasil kajian beberapa literatur. Analisis data dilakukan secara deskriptif dengan menyajikan ukuran tendency central dan distribusi frekuensi dari data hasil penelitian, baik melalui penyajian tekstual maupun tabular. Selanjutnya diulas secara menyeluruh berdasarkan teori-teori dan hasil-hasil penelitian sebelumnya, melalui berbagai mekanisme yang mendasari keterkaitan gangguan fungsi tiroid dan karakteristik biopsikososial.

\section{HASIL DAN PEMBAHASAN}

Pengukuran kadar TSH dan FT4 pada subjek, sebagai indikator untuk mengetahui adanya gangguan fungsi tiroid, menunjukkan hasil rata-rata TSH sebesar 1,10 $\pm 1,02 \mu \mathrm{U} / 1$, sedangkan rata-rata kadar FT4 sebesar 0,85 $\pm 0,271$ $\mathrm{ng} / \mathrm{dl}$. Interpretasi terhadap gangguan fungsi tiroid, didasarkan pada kedua jenis hormon tersebut, dengan kriteria seperti tersaji pada Tabel 1.

\section{Tabel 1. Distribusi Gangguan Fungsi Tiroid}

Berdasarkan TSH dan FT4

\begin{tabular}{lcc}
\hline Kriteria & Frekuensi (n) & Persentase (\%) \\
\hline Hipotiroid subklinis & 1 & 2,00 \\
Eutiroid & 36 & 72,00 \\
Hipertiroid subklinis & 13 & 26,00 \\
\hline Jumlah & 50 & 100,00 \\
\hline
\end{tabular}

Menyimak Tabel 1, penelitian ini menemukan ada 3 kriteria gangguan fungsi tiroid pada wanita usia produktif, yakni sebagian besar adalah fungsi tiroid normal (eutiroid) sebesar $72 \%$, hipotiroid subklinis $2 \%$ dan hipertiroid subklinis $26 \%$.

Karakteristik biopsikososial sebagai dampak dari gangguan fungsi tiroid yang digali pada penelitian ini, didasarkan pada hasil kajian literatur dan mensintesis 9 domain, yang masing-masing domain diwakili oleh item tanda dan gejala gangguan fungsi tiroid yang merupakan manifestasi dari aspek biologis dan psikososial (Tabel 2) 
Tabel 2. Domain dan Item Karakteristik Biopsikososial sebagai

Dampak Gangguan Fungsi Tiroid

\begin{tabular}{ll}
\hline \multicolumn{1}{c}{ Domain } & \multicolumn{1}{c}{ Item-item } \\
\hline Gangguan yang berkaitan dengan goiter & $\begin{array}{l}\text { Sesak di leher, tekanan di kerongkongan, terasa } \\
\text { gumpalan di kerongkongan, tidak nyaman saat } \\
\text { menelan, kesulitan menelan, ada perubahan suara/ } \\
\text { parau } \\
\text { Pembengkakan muka (puffiness face), tangan dan kaki, } \\
\text { kulit kering dan bersisik, kulit sangat lembek } \\
\text { Gensitif perubahan suhu (cold/heat intolerance), gang- } \\
\text { guan koordinasi gerak, eksoftalmus, tremor }\end{array}$ \\
Gangguan persyarafan & $\begin{array}{l}\text { Kejang otot, nyeri sendi, lemah otot, mudah lelah } \\
\text { Penurunan konsentrasi, kesulitan mengingat }\end{array}$ \\
Gangguan muskuloskeletal & $\begin{array}{l}\text { Menstruasi tidak teratur, penurunan libido, penu- } \\
\text { runan aktivitas seksual }\end{array}$ \\
Gangguan kognisi & Konstipasi, diare \\
Gangguan seksual & Cemas, gugup, gangguan tidur, merasa sedih, tidak \\
bahagia, tertekan, mudah marah, iritabilitas & Penurunan motivasi hidup bersama dengan orang \\
Gangguan gastrointestinal & lain, penurunan aktivitas sosial sehari-hari, apatis, \\
Gangguan psikologis & suka menyendiri \\
Gangguan interaksi sosial &
\end{tabular}

Sebelumnya pada Tabel 1. telah disajikan deskripsi distribusi frekuensi dari gangguan fungsi tiroid pada wanita usia produktif, dan ditemukan ada 1 subjek ( $2 \%$ ) tergolong hipotiroid subklinis dan 13 subjek (26\%) tergolong hipertiroid subklinis. Selanjutnya akan disajikan karakteristik biopsikososial yang dialami oleh subjek pada kedua jenis gangguan fungsi tiroid tersebut (Tabel 3).

Tabel 3. Karakteristik Biopsikososial pada Subjek Hipotiroid dan Hipertiroid

\begin{tabular}{|c|c|}
\hline Kriteria fungsi tiroid & Karakteristik biopsikosial \\
\hline Hipotiroid subklinis $(\mathrm{n}=1)$ & $\begin{array}{l}\text { Biologis : visible goiter, muka sembab, kulit kering, mudah lelah, } \\
\text { penurunan konsentrasi, menoragia. } \\
\text { Psikososial: mudah sedih, merasa tertekan, apatis, suka } \\
\text { menyendiri }\end{array}$ \\
\hline Hipertiroid subklinis $(n=13)$ & $\begin{array}{l}\text { Biologis: palpable goiter }(7,7 \%) \text {; sensitif suhu panas }(23,1 \%) \text {; } \\
\text { eksoftalmus sedang }(7,7 \%) \text {; mudah lelah }(84,6 \%) \text {; edema kaki } \\
(7,7 \%) \text {; lemah otot }(38,5 \%) \text {; kulit lembek }(15,4 \%) \text {; kesulitan } \\
\text { mengingat }(30,7 \%) \text {; penurunan konsentrasi }(61,5 \%) \text {; gangguan } \\
\text { menstruasi }(7,7 \%) \text {. } \\
\text { Psikososial: cemas }(53,8 \%) \text {; gangguan tidur }(53,8 \%) \text {; mudah } \\
\text { marah }(61,5 \%) \text {; penurunan motivasi }(53,8 \%) \text {; penurunan aktivitas } \\
\text { sosial }(46,1 \%) \text {. }\end{array}$ \\
\hline
\end{tabular}


Setidaknya ada 3 alasan utama TSH menjadi indikator yang baik untuk mendeteksi penyakit gangguan fungsi tiroid, yakni adanya hubungan loglinier terbalik antara konsentrasi TSH dan FT4. Hampir semua kasus hipotiroidisme dan hipertiroidisme yang umumnya ditemui dalam praktek medis disebabkan oleh penyakit primer (kelenjar tiroid), sehingga berkaitan dengan hormon yang merangsang aktivitas tiroid yakni TSH. Alasan selanjutnya, tes immunometric untuk TSH adalah tes yang sangat sensitif dan spesifik, dengan sensitivitas dan spesifisitas yang lebih tinggi dari 99\% (Guan et al, 2008).

Interpretasi kadar TSH dalam serum, biasanya didefinisikan dengan interval referensi normal sekitar 0,4-4,0 $\mu \mathrm{U} / 1$, sedangkan interval referensi normal untuk kadar FT4 berkisar 0,72,1 ng/dl (Stockigt, 2010). Defisiensi yodium yang berlangsung dalam jangka panjang akan meningkatkan kadar TSH, tetapi produksi hormon tiroksin dalam kadar normal yang konstan, kondisi ini dikenal sebagai hipotiroidisme subklinis. Sebaliknya, bila kadar TSH menurun tetapi produksi hormon tiroksin dalam kadar normal disebut sebagai hipertiroidisme subklinis. Jika pada kedua kondisi tersebut kadar FT4 terlalu rendah dan terlalu tinggi, maka disebut sebagai hipotiroid klinis dan hipertiroid klinis (Brown et al., 2005, Zimmerman, 2009).
Penelitian ini menemukan 1 kasus subjek dengan hipotiroid subklinis, yakni dengan kadar TSH melebihi batas normal meski tidak sangat ekstrim $(4,90 \mu U / 1)$. Sementara itu, pada 13 subjek (26\%) dengan hipertiroid subklinis (TSH $<0,4 \mu \mathrm{U} / 1$ ), sebanyak 8 subjek menunjukkan kadar TSH sangat rendah $(<0,004 \mu \mathrm{U} / 1)$. Penemuan subjek hipertiroid subklinis sebesar $26 \%$ ini memperkuat beberapa penelitian mengenai adanya fenomena ekses yodium yang berdampak pada kecenderungan penurunan kadar TSH pada subjek di daerah endemis defisiensi yodium (Alsayed et al., 2008, Watt., 2009). Bahkan Hermann, et al (2004), menemukan angka yang ekstrim, kejadian ekses yodium pada anak sekolah mencapai $84 \%$.

Defisiensi yodium merupakan penyebab utama hipotiroidisme dan hipertiroidisme, dengan persentase terbesar masing-masing sebesar 30,9\% dan 19,3\%, dibandingkan penyebabpenyebab lainnya (Lamfon, 2008). Hipotiroid terjadi sebagai konsekuensi fungsional pertama dari defisiensi yodium, melalui peningkatan penyerapan yodida oleh tiroid yang dimediasi melalui protein trans membran yakni natrium iodida symporter (NIS). Penyerapan yodida yang meningkat, sangat mungkin disertai oleh dan sebagai akibat dari peningkatan serum TSH (Zimmerman, 2009). 
Defisiensi yodium juga dapat menyebabkan hipertiroid, melalui mekanisme iodine induced hyperthyroidism, antara lain karena suplementasi yodium di daerah endemis yang tidak terpantau dengan baik, ekses yodium karena terapi obat antitiroid, ekses obatobatan yang mengandung kadar yodium tinggi seperti amiodarone dan ekspektoran termasuk glycerol dan organidin, media kontras seperti tomografi atau arteriografi, air minum dengan yodium yang berlebihan, penggunaan antiseptik pada industri makanan dan minuman terutama produk susu, industri makanan dan minuman dengan bahan baku kaya yodium seperti rumput laut atau adanya fortifikasi yodium (Pearce et al, 2002).

Ekses yodium sebagai penyebab hipotiroidisme banyak dijelaskan melalui mekanisme efek Wolff-Chaikoff, yakni yodium dalam jumlah yang berlebihan pada kondisi kelenjar tiroid kekurangan yodium, justru akan menghambat sintesis hormon tiroid. Sebagai adaptasi dari efek Wolff-Chaikoff, yang meningkatkan konsentrasi yodium intratiroid, menyebabkan yodida yang tertangkap tiroid menurun, kemudian menurunkan yodida intratiroid dan menurunkan NIS mRNA dan ekspresi protein. Ekses yodium juga menurunkan pelepasan T4 dan T3 dari tiroid, dengan sedikit penurunan kadar T4 dan T3 dan kompensasi meningkatnya TSH. Sebaliknya, ekses yodium sebagai penyebab hipertiroidisme dijelaskan melalui mekanisme thyroid autoimmunity melalui efek Jod Basedow. Penyakit autoimun tiroid terjadi karena tubuh menghasilkan antibodi yang bekerja mirip dengan TSH, yang mampu merangsang reseptor TSH (thyrotropin receptor antibody $=\mathrm{TRAb}$ ) untuk menghasilkan T4 (tiroksin) dan T3 (triiodotironin) yang berlebihan, sehingga berdampak hipertiroidisme (Zimmerman., 2009, Pearce et al., 2002, Ahad et al., 2010).

Berkaitan dengan aspek biopsikososial, gangguan fungsi tiroid mempunyai berbagai mekanisme yang mendasari patofisiologis, dari setiap tanda dan gejala yang menyertai. Hipotiroid karena defisiensi yodium menyebabkan goiter, karena pengambilan mutlak yodida berkurang dan kadar yodium dalam tiroid menurun. Di bawah tingkat kritis asupan yodium tersebut, terjadi peningkatan clearance iodida, untuk mempertahankan penyerapan yodida absolut normal oleh tiroid. Konsekuensi agar kadar yodium organik tiroid tetap dalam batas normal, adalah timbulnya goiter. Goiter juga timbul pada kasus hipertiroid, pada dasarnya disebabkan oleh aktivitas kelenjar tiroid yang berlebihan dalam mensekresi hormon tiroid. Bisa terjadi karena asupan yodium berlebihan atau karena terjadinya peningkatan metabolisme semua zat gizi yang berdampak pada peningkatan glomerular filtration rate (GFR), sehingga meningkatkan yodium yang keluar melalui ginjal. 
Kondisi ini akan menurunkan yodium dalam plasma, yang menimbulkan kompensasi pada kelenjar tiroid untuk mencukupi kebutuhan hormon tiroid dengan meningkatkan aktivitasnya, sehingga timbul goiter (Zimmerman, 2009).

Subjek dengan hipotiroid memperlihatkan muka yang sembab (puffiness face), dikarenakan adanya penurunan metabolisme karbohidrat dan protein, yang menyebabkan meningkatnya water binding glycosaminoglycans dan meningkatnya transcapillary escape of albumin (meningkatnya albumin ektravaskular), selain itu menurunnya GFR, akan menurunkan creatinine clearance sehingga terjadilah edema. Pada subjek hipertiroid, edema yang timbul pada kaki bagian bawah (pretibial edema), disebabkan karena dengan meningkatnya hormon tiroid akan meningkatkan simpanan glikosaminoglikan, sehingga meningkatkan tekanan osmotik dan meningkatkan penimbunan cairan terutama di daerah ekstremitas bagian bawah (Wiersinga, 2010).

Kulit kering dan bersisik serta teraba sangat dingin pada subjek hipotiroid, sebagai akibat dari metabolisme yang menurun serta vasokonstriksi kulit. Kekeringan pada kulit disebabkan berkurangnya sekresi kelenjar keringat dan sebase. Perubahan karakteristik kulit ini disebabkan juga oleh peningkatan jumlah glikosami-noglikan, sebagai akibat dari katabolisme mukopolisakarida dan kolagen oleh fibroblas kulit. Sementara itu gejala kulit yang sangat lembek dan selalu basah pada subjek hipertiroid, disebabkan oleh peningkatan jumlah keringat sebagai kompensasi hipotalamus untuk menurunkan suhu tubuh karena peningkatan produksi panas yang diakibatkan oleh peningkatan basal metabolism rate (BMR) (Wiersinga, 2010).

Keluhan sangat mudah lelah, pada hipotiroid disebabkan oleh penurunan metabolisme oksidatif mitokondria, yang tercermin dari peningkatan rasio anorganik fosfat untuk ATP dalam otot saat istirahat dan penurunan tajam dalam fosfokreatin dalam otot yang aktif. Pengurangan kalsium ATPase juga akan muncul untuk menjelaskan salah satu manifestasi klinis yang paling jelas dari hipotiroidisme, yaitu: relaksasi yang lambat dari refleks tendon dalam, mialgia, kelemahan otot, kekakuan, kram, kelelahan, arthralgias, kekakuan sendi, efusi sendi dan tulang, pseudogout, serta carpal tunnel syndrome (Wiersinga, 2010).

Kelelahan yang timbul pada hipertiroid, disebabkan adanya peningkatan metabolisme yang menyebabkan pemakaian energi secara cepat, sehingga sumber energi menurun dengan cepat. Selain itu dengan metabolisme yang meningkat, maka produksi panas meningkat, memacu keluarnya keringat dan dehidrasi, sehingga mudah mengalami kelelahan. Meningkatnya produksi panas pada subjek hipertiroid, juga akan meningkatkan suhu 
tubuh, sehingga lebih sensitif atau tidak tahan terhadap suhu panas.

Gangguan menstruasi yang timbul pada subjek hipotiroid, ditandai oleh banyaknya darah yang keluar dan atau periode menstruasi yang lebih lama (menoragia), dikarenakan rendahnya aktivitas hormon tiroid yang menyebabkan gangguan pada hypotalamicpituitary ovarian axis, sehingga menimbulkan ketidakseimbangan kadar estrogen dan progesteron, sebagai kompensasi atas ketidakseimbangan ini terjadilah heavy bleeding dalam endometrium. Subjek hipertiroid juga mengalami gangguan menstruasi, ditandai oleh sedikitnya jumlah darah menstruasi atau ketidak-teraturan menstruasi, yang bisa terjadi 2 atau 3 bulan sekali (hipomenore dan amenore). Umumnya penyebab ame-nore adalah primary ovarian failure (hipergonadotropik hipogonad), yang bisa terjadi karena menurunnya kadar TSH, yang menyebabkan hipertirok-sinemia sehingga meningkatkan gonadotropin releasing hormone ( $\mathrm{GnRH})$. Sementara itu adanya keluhan berkurangnya libido seksual pada subjek hipertiroid, selain karena ketidak-seimbangan hormon seksual, juga lebih banyak dijelaskan melalui mekanisme kecemasan (Sirichand et al, 2009).

Penurunan konsentrasi dan daya ingat pada subjek hipotiroid, melalui mekanisme menurunnya metabolisme basal yang menyebabkan penurunan pemakaian oksigen, sehingga menu- runkan sintesis neurotransmiter dan menurunkan cytokines release dalam otak. Keadaan tersebut akan menurunkan produksi neuromodulator dan mengganggu proses yang berkaitan dengan neurochemical, neuroendocrine, neuroimmune, dan behavioral change, yang berdampak kondisi psikologis termasuk kemampuan kognitif, seperti penurunan konsentrasi dan daya ingat. Gangguan kognitif pada subjek hipertiroid seperti sulit berkonsentrasi dan sering lupa, lebih disebabkan oleh adanya penurunan thyroid releasing hormone (TRH) yang menyebabkan peningkatan sintesis dan pelepasan asetilkolin sehingga mengganggu fungsi otak (Cereseni et al, 2009).

Kelemahan otot (muscle weakness) yang dialami subjek hipertiroid, diawali dari peningkatan metabolisme tubuh karena peningkatan aktivitas hormon tiroid, selanjutnya terjadi peningkatan pemecahan protein dan menurunkan kapasitas fungsi kontraksi di dalam otot skeletal. Kelemahan otot ini sering menyebabkan subjek kehilangan motivasi dan malas untuk berinteraksi dengan lingkungan disekitarnya, serta berupaya mengurangi aktivitas sehari-hari (Wiersinga, 2010). Subjek hipertiroid dengan eksoftalmus (mata membelalak), disebabkan oleh adanya edema dan infiltrasi lemak yang menyebabkan distropi otot-otot luar mata, sehingga timbul progressive protrusion of eyeball. Mekanisme lain berkaitan dengan autoantibodi yang 
menimbulkan reaksi autoimun dan menyebabkan infiltrasi limfosit, sel mast dan sel plasma, yang selanjutnya terjadi inflamasi serta pembengkakan jaringan retro orbita (DeGroot, 2010).

Gejala psikososial pada subjek hipotiroid, seperti mudah sedih, merasa tertekan, tidak bersemangat dan apatis serta lebih suka menyendiri, disebabkan oleh adanya mekanisme yang berkaitan dengan aspek biologis hipotiroid terhadap depresi, melalui serangkaian proses yang berkaitan dengan CSF CCK-4, yakni kolesistokinin peptida dalam cairan serebrospinal dan triptopan (prekursor serotonin), yang menurun kadarnya sehingga meningkatkan kadar TSH. Depresi juga berhubungan dengan rendahnya serotonergik (5-HT) dalam otak, yang diakibatkan karena gangguan pada hypotalamic-pituitary thyroid axis (Brown et al, 2005).

Kecemasan yang dialami oleh subjek hipertiroid, dapat dijelaskan melalui mekanisme adanya proliferasi reseptor adrenergik yang membuat sel target sensitif terhadap katekolamin, sehingga meningkatkan komponenkomponen yang menciptakan kecemasan. Selain itu, peningkatan hormon tiroid akan meningkatkan aktivitas CNS, merangsang syaraf simpatis dan meningkatkan epinefrin dan kortisol yang memacu kecemasan (Brown et al, 2005). Tidak jauh berbeda, mekanisme pada subjek hipertiroid yang mudah marah, disebabkan karena aktivitas kelenjar tiroid yang berlebihan akan memacu proliferasi reseptor â adrenergik, dan meningkatkan efek katekolamin sehingga subjek tidak rileks dan lebih sensitif. Sementara itu, gangguan tidur yang dialami subjek hipertiroid, terjadi melalui mekanisme peningkatan metabolisme tubuh, pemakaian oksigen dengan cepat, curah jantung meningkat, perasaan berdebar-debar, dan tidak rileks, sehingga tidur tidak nyenyak. Mekanisme lain karena peningkatan produksi panas dan keringat yang menyebabkan gelisah dan sering terbangun ketika tidur (Bunevicius and Prange, 2006).

\section{KESIMPULAN DAN SARAN}

\section{A. Kesimpulan}

Berdasarkan kadar TSH dan FT4, gangguan fungsi tiroid pada wanita usia produktif di daerah endemis defisiensi yodium, dapat dikategorikan hipotiroid subklinis sebesar $2 \%$, hipertiroid subklinis $26 \%$ dan eutiroid sebesar $76 \%$. Dengan demikian dapat ditemukan fakta bahwa ada kecenderungan adanya kasus hipertiroid subklinis di daerah endemis defisiensi yodium. Ditemukan berbagai tanda dan gejala yang mencakup aspek biopsikososial, sebagai dampak gangguan fungsi tiroid yang bisa dijelaskan interaksinya, melalui mekanisme-mekanisme secara timbal balik antara aspek biologis dan psikososial. Karakteristik biopsikososial pada subjek hipotiroid subklinis, 
diantaranya: visible goiter, muka sembab, kulit kering, mudah lelah, penurunan konsentrasi, menoragia, mudah sedih, merasa tertekan, apatis dan suka menyendiri. Sementara itu, subjek hipertiroid subklinis dengan persentase yang bervariasi menunjukan tanda dan gejala diantaranya adalah palpable goiter, sensitif suhu panas, eksoftalmus sedang, mudah lelah, edema kaki, lemah otot, kulit lembek, kesulitan mengingat, penurunan konsentrasi, gangguan menstruasi, penurunan libido seksual, cemas, gangguan tidur, mudah marah, penurunan motivasi dan penurunan aktivitas sosial.

\section{B. Saran}

Mengingat adanya kecenderungan ekses yodium di daerah ende- mis defisiensi yodium, dan mengkaji dampak defisiensi dan ekses yodium terhadap gangguan fungsi tiroid, serta bermanifestasi luas terhadap karakteristik biopsikososial, maka diperlukan pemantauan secara berkelanjutan terhadap program-program eliminasi defisiensi yodium. Dengan demikian permasalahan baru seperti ekses yodium sebagai dampak dari intervensi terhadap defisiensi yodium, bisa dicegah dan tidak berkelanjutan. Upaya peningkatan pemahaman masyarakat akan dampak gangguan fungsi tiroid terhadap aspek biopsikososial juga perlu dilakukan, agar masyarakat mempunyai self awareness sekiranya merasakan tanda dan gejala yang berkaitan dengan gangguan tiroid, maka bisa segera mendapatkan pemeriksaan lebih lanjut di tempat pelayanan kesehatan.

\section{DAFTAR PUSTAKA}

Ahad, F., and Ganie, S.A. 2010. Iodine, Iodine Metabolism and Iodine Deficiency Disorders Revisited. Indian Journal of Endocrinology and Metabolism 14(1): 1317.

Alsayed. A., Gad, A.M., Baset, H.A., Fattah, A.A., Ahmed, A., and Azab, A. 2008. Excess Urinary Iodine is Associated with Autoimmune Subclinical Hypothyroidsm among Egyptian Women. Endocrine Journal 55(3): 601-605.

Bayram, F., Beyazyildiz, A., Gokce, C., Budak, N., Erdogan, N., Kurtoglu, S., Kula, M., Unluhizarci, K., and Kelestimur, S. 2009. The Prevalence of Iodine Deficiency, Serum Thyroglobulin, Anti-Thyroglobulin and Thyroid Peroxidase Antibody Levels in The Urban Areas of Kayseri, Central Anatolia. Experimental and Clinical Endocrinology and Diabetes 117(2): 64-68. 
Brown, B.T., Bonello, R., and Pollard, H. 2005. The Biopsychosocial Model and Hypothyroidism. Chiropractic \& Osteopathy 13(5): 1-9.

Bunevicius, R., Prange, A.J., 2006. Psychiatric Manifestations of Graves' Hyperthyroidism Pathophysiology and Treatment Options. Central Nervous System Drugs 20 (11): 897-909.

Ceresini, G., Lauretani, F., Maggio, M., Ceda, G.P., Morganti, S., and Usberti, E. 2009. Thyroid Function Abnormalities and Cognitive Impairment in The Elderly. Results of The InCHIANTI Study. Journal of the American Geriatrics Society 57(1): 89-93.

Charlton, K.E, Gemming, L., Yeatman, H., and Ma, G. 2010. Suboptimal Iodine Status of Australian Pregnant Women Reûects Poor Knowledge and Practices Related to Iodine Nutrition. Nutrition 26: 963-968.

DeGroot, L.J. 2010. Diagnosis and Treatment of Graves' Disease. University of Rhode Island, Washington. Published: www.thyroidmanager.org. Accessed: Mart $20^{\text {th }} 2011$.

Delshad, H., Mehran, L., Azizi, F. 2010. Appropriate Iodine Nutrition in Iran: 20 Years of Success. Acta Medica Iranica 48(6): 361-366.

Fountoulakis, S., Philippou, G., and Tsatsoulis, A. 2007. The Role of Iodine in The Evolution of Thyroid Disease in Greece: from Endemic Goiter to Thyroid Autoimmunity. Hormones 6(1): 25-35.

Guan, H., Shan, Z.,, Teng, X., Li, Y., Teng, D., and Jin, Y. 2008. Influence of Iodine on The Reference Interval of TSH and The Optimal Interval of TSH: Results of a Follow-up Study in Areas with Different Iodine Intakes. Clinical Endocrinology 69: 136-141.

Hermann, D., Hewer, W., and Lederbogen, F. 2004. Testing The Association between Thyroid Dysfunction and Psychiatric Diagnostic Group in An IodineDeficient Area. Journal of Psychiatry and Neuroscience 29(6): 444-449.

Henjum, H., Barikmo, I., Gjerlaug, A.K., Lehabib, A.M., Oshaug, A., Strand, T.A., and Torheim, L.E. 2010. Endemic Goitre and Excessive Iodine in Urine and Drinking Water among Saharawi Refugee Children. Public Health Nutrition 13(9): 1472-1477.

Lamfon, H.A. 2008. Thyroid Disorders in Makkah, Saudi Arabia. Ozean Journal of Applied Sciences 1(1): 55-58.

Medani, A.M.M.H., Elnour, A.A., and Saeed, A.M. 2011. Endemic Goitre in The Sudan Despite Iong-Standing Programmes for The Control of Iodine Deficiency Disorders. Bulletin of The World Health Organization 89: 121-126.

Kajian Patofisiologis Gejala Klinis dan Psikososial ... (Mutalazimah, dkk.) 
Mutalazimah, and Asyanti, S. 2010. Angka Kecerdasan Anak Sekolah Menurut Perspektif Kadar Yodium dalam Urin. Jurnal Nutrisia 12(1): 1-7.

Novack, D.H., Cameron, O., Epel, E., Ader, R., Waldstein, S.R., Levenstein, S., Antoni, M.H., and Wainer, A.R. 2007. Psychosomatic Medicine: The Scientiûc Foundation of The Biopsychosocial Model. Academic Psychiatry 31: 388-401.

Pearce, E.N., Gerber, A.R., Gootnick, D.B.,, Khan L.K., Li, R., Sampino, and Braverman, L.E. 2001. Effects of Chronic Iodine Excess in A Cohort of LongTerm American Workers in West Africa. The Journal of Clinical Endocrinology $\mathcal{E}$ Metabolism 87(12): 5499-5502.

Sebotsa, M.L.D., Dannhauser, A., Mollentze, W.F., Oosthuizen, G.M., Mahomed, F.A., and Jooste, P.L. 2009. Knowledge, Attitudes and Practices Regarding Iodine among Patients with Hyperthyroidism in The Free State, South Africa. South African Journal of Clinical Nutrition 22(1): 18-21.

Sirichand, P., Devrajani, B.R., Abbasi, R.M., Shah, S.Z.A., Devrajani, T., and Bibi, I. 2009. Impaired Thyroid Function in Patient with Menstrual Disturbance (An Experience of A Private Clinic). World Applied Sciences Journal 7(4): 538-542.

Stockigt, J. 2010. Clinical Strategies in The Testing of Thyroid Function. Monash University and Alfred and Apworth Hospital, Melbourne, Australia. Published by: www.thyroidmanager.org. Accessed : January $7^{\text {th }} 2011$.

Tim GAKY Pusat. 2005. Rencana Aksi Nasional Kesinambungan Program Penanggulangan Gangguan Akibat Kurang Yodium, Tim GAKY Pusat, Jakarta.

Watt, T. 2009. Development of A Danish Thyroid-Specific Quality of Life Questionnaire. PhD Rigshospitalet and Health Service Research. Institute of Public Health.

Wang, Y., Zhang, Z., Ge, P., Wang, Y., and Wang, S. 2009. Iodine Deficiency Disorders after A Decade of Universal Salt Iodization in A Severe Iodine Ddeficiency Region in China. Indian Journal of Medical Research 130: 413-417.

Wiersinga, W.M. 2010. Adult Hypothyroidism. Published by: www.thyroidmanager.org Accessed: May $8^{\text {th }} 2011$.

Zimmerman, M.B. 2009. Iodine Deficiency in Pregnancy and The Effects of Maternal Iodine Supplementation on The Offspring: A Review. American Journal of Clinical Nutrition 89(suppl):668S-72S. 